\title{
YOUTH TRAVEL EXPERIENCE: AN ANALYSIS OF THE RELATIONS BETWEEN MOTIVATIONS, SATISFACTION AND PERCEIVED CHANGE
}

\author{
SIMONA STAFFIERI ${ }^{1,2} \&$ ELENA CAVAGNARO ${ }^{2}$ \\ ${ }^{1}$ University of Rome La Sapienza, Italy \\ ${ }^{2}$ Stenden University of Applied Sciences, The Netherlands
}

\begin{abstract}
This paper aims at identifying the relation between motivation and satisfaction understood as components of the travel experience, and, at the same time, the impact of both on perceived change, considered as a multidimensional construct. Change is hereby conceptualized not only as personal and interpersonal change, but also as change in the relationship between the traveller and the natural environment. The study focuses on young travellers because they constitute a substantial market segment which importance to the industry is expected to increase in the future and because they are an innovative force leading the whole tourism market towards new choices. In a quantitative research design, existing scales were used to measure change, motivation to travel and satisfaction. Data was collected in August 2015 at a Dutch University of Applied Sciences (UAS) using a Computer Assisted Web Interview (c.a.w.i.) which reached students between 16 and 30 years of age fitting the definition of young travellers. The self-selected sample consists of 395 respondents of which 314 have travelled independently. Out of these 314, only 256 questionnaires were completed in all relevant sections. A structural equations model has been used to test the link between the observed variables regarding motivation, satisfaction and perceived change. This model combines the logic of factor analysis with multiple regressions and explains relationships through a simultaneous equations model. Results show that the motivation and the degree of satisfaction with the tourism experience exert an important influence on the change perceived by the young traveller. This study therefore confirms the transformative power of the travel experience and adds that the transformation cannot be understood if the motivation to travel and the satisfaction with the travel experience are ignored.

Keywords: tourism motivation, satisfaction and perceived change.
\end{abstract}

\section{INTRODUCTION}

The transformative power of travelling is a wide referred to concept in the literature [1], [2]. However, existing studies mostly frame the change as improvement in the quality of life [3] and health of the traveller; as perceived well-being or wellness benefits after travelling [4], [5] and as the result of learning processes that can be active, such as when a travel is undertaken for study purposes, or passive, thus not intentionally looked for but achieved through comparing foreign customs, principles, and values to the traveller's own ones [6], [7]. Consequently, perceived change has been conceptualized as intrapersonal and interpersonal, with limited consideration toward change in the relationship between the traveller and nature. The lack of attention for the relation between the traveller and the natural environment is surprising because there is a shared but seldom researched expectation that travelling may increase people awareness of the beauty and fragility of nature and thus foster a more environmentally conscious form of tourism [8]. Moreover, studies seldom consider the influence on the perceived change of specific components of the travel experience, such as motivation and satisfaction [9].

Finally, and considering specifically the target group of this study, young travellers, it should be noted that literature tends to focus on specific travel experiences, such as a gap year, and not on travel in general. There is therefore a need to better conceptualize the transformative power of travelling in general, and in relation to sustainable tourism and 
younger travellers. The present study is one in a series dedicated to better understanding change through travel. Previous studies in this line have examined the concept of change and shown that young travellers report to feel changed not only in their relationship with the self and with others, but also in their relationship with nature - a change that was labelled as 'All' or 'transpersonal' to distinguish it from intrapersonal ('Me and You') and interpersonal ('Me') change [10]. Moreover, it has been demonstrated that traveling in general is conductive of these three types of change in youngster, and not only a specific travel such as a gap year or eco-tourism [9]-[11].

Finally, it has been shown that the components meaning, and satisfaction of a travel experience influence the perceived intrapersonal and interpersonal change [11]. This study wishes to set a further step in this line by assessing whether motivation and satisfaction influence all three types of change, thus including transpersonal change. In the following, first we will review the main literature on youth tourism experience, with an emphasis on motivation and satisfaction, and change through travel. Then the research method will be discussed followed by a presentation of the findings. A critical discussion of the results and their implications closes the article.

\subsection{Youth tourism}

Youth tourism has been increasingly considered an important area of research, for several reasons. Young tourists are resilient in the face of economic and political turmoil and may therefore provide socio-economic benefits to these communities that are most in need of them [2]. Moreover, young tourists represent a growing market in several countries [12], [13], while the image attached to them of pioneers and innovators give youngsters a form of intangible power that might set new trends and lead to new styles of tourism for society at large [14]. Moreover, they are saluted as being not only an important market in current tourism but also as being the tourists of the future [15], [16]. Understanding young traveller's behaviour is therefore essential to the future survival of tourism-related businesses [12], [13], [17].

The definition of youth tourism given by UNWTO and WYSE Travel Confederation refers to all the independent journeys for periods of less than one year, undertaken by people aged 16-29 and driven by a wish to observe other cultures, improve life knowledge and take advantages from learning in an external environment [15]. Independence is a significant component in youth tourism because it leads to additional development in the traveller's behaviour and character [17], [18]. At present (2018), the definition adopted in this study includes the millennials generation, born between 1980 and 2000. This generation is permanently connected to the word and with peers, thanks to their close relation with technology and strong digital capabilities [12]. They are natural travellers [19], to crave for experiences [16], to reject uniform products, to harbour altruistic and biospheric values [13], [20], and to seek for new solutions and outstanding practises that create emotions [12], [21].

\subsection{Travel experience's components: motivation, satisfaction and perceived change}

The need to travel, the consumption of the experience itself and its evaluation constitute the components of the tourism experience. The first dimension (need) in its turn, includes two components: meaning of and motivation to travel, while the evaluation dimension includes satisfaction and perceived change [9]. This study focuses on the components motivation, satisfaction and change. 
Motivations ignite the decision-making process leading to a certain tourism experience [22]. Therefore, understanding motivations is essential, especially from a marketing point of view, as it allows the development of offers tailored to the target group - here young tourists [23]. Motivation is moreover an important element of human actions [14] and in the tourist context it is characterized by the dichotomy between internal (socio-psychological factors) and external (attractiveness of the tourist destination) motivations [14], [24]. Though in general studies on tourism motivation were not specifically directed to youngsters, it has been proved that young travellers share this ample set of motivation [9], [13], [25], [26]. Previous studies identified a wide range of motivations that includes the attractiveness of the destination, cultural growth, breaking from everyday life, fun, wellbeing, socialization and fashion [14], [25]-[27]. As in the existing literature there is no consensus on how to conceptualize and measure motivations, the present work includes a large variety of items that have been linked to motivation. Through statistical analysis it then proposes a classification in sub-dimensions [9]. This research uncovers four motivations as synthetic latent variables emerging from the items reported in Table 1, that were measured using a Likert scale $1-5$ for each one.

Table 1: The observed items and latent variables considered in the model.

\begin{tabular}{|c|c|c|}
\hline Code & Motivation items & Latent variable \\
\hline M3 & I took the travel to see the beauty of the place & \multirow{4}{*}{$\begin{array}{c}\text { Mot1: } \\
\text { Eco-sustainable } \\
\text { motivation }\end{array}$} \\
\hline M10 & I took the travel to be in contact with nature & \\
\hline M11 & I took the travel to experience beautiful natural landscapes & \\
\hline M12 & $\begin{array}{l}\text { I took the travel to observe animals that are not living in the country I come } \\
\text { from }\end{array}$ & \\
\hline M1 & I took the travel to have fun & \multirow{4}{*}{$\begin{array}{c}\text { Mot2: } \\
\text { Fun and escaping }\end{array}$} \\
\hline M2 & I took the travel to relax & \\
\hline M4 & I took the travel to have a break from everyday life & \\
\hline M7 & I took the travel to interact with my friends & \\
\hline M8 & $\begin{array}{l}\text { I took the travel because most people think that it is necessary to do at least } \\
\text { once in life }\end{array}$ & \multirow{2}{*}{$\begin{array}{l}\text { Mot3: } \\
\text { Vogue }\end{array}$} \\
\hline M9 & $\begin{array}{l}\text { I took the travel because by discussing my plans with friends on social media } \\
\text { (such as Facebook) I raised the impression that I would do it }\end{array}$ & \\
\hline M5 & I took the travel to feel more independent & \multirow{2}{*}{ Mot4: Independence } \\
\hline M6 & I took the travel to interact with other people & \\
\hline Code & Satisfaction items & Latent variable \\
\hline S1 & The travel experience gave me back a deep sense of joy and fulfilment & \multirow{6}{*}{$\begin{array}{c}\text { Sodd: } \\
\text { General satisfaction }\end{array}$} \\
\hline S2 & The travel was a positive experience & \\
\hline S3 & I found happiness from my travel & \\
\hline S4 & I consider the travel experience favourably & \\
\hline S5 & I would like to repeat this travel experience & \\
\hline S6 & I will recommend to others to do the same travel & \\
\hline Code & Perceived change items & Latent variable \\
\hline $\mathrm{C} 1$ & The travel experience has contributed to my personal growth & \multirow{5}{*}{$\begin{array}{c}\text { ch1: } \\
\text { Change 'Me' }\end{array}$} \\
\hline $\mathrm{C} 4$ & The travel experience changed my way of being & \\
\hline C5 & The travel experience allowed me to know myself better & \\
\hline C6 & The travel experience changed my life & \\
\hline $\mathrm{C} 7$ & The travel experience opened my horizons & \\
\hline $\mathrm{C} 8$ & The travel experience helped me to feel in contact with nature & \multirow{3}{*}{$\begin{array}{c}\operatorname{ch} 2: \\
\text { Change 'All' }\end{array}$} \\
\hline C9 & The travel experience changed my relationship with the natural environment & \\
\hline $\mathrm{C} 10$ & The travel experience convinced me that we need to protect natural resources & \\
\hline $\mathrm{C} 2$ & The travel experience helped me gain a greater cultural awareness & \multirow{2}{*}{$\begin{array}{c}\text { ch3: } \\
\text { Change 'Me and You' }\end{array}$} \\
\hline $\mathrm{C} 3$ & The travel experience increased my openness to other cultures & \\
\hline
\end{tabular}


Satisfaction is a cognitive concept and is understood as the consumer's response to the provided service and product quality in relation to expectations [28]. It is a multidimensional construct [29] and some scholars, to the knowledge of the satisfaction have added the theme of emotions as determinant of its measure [30], [31]. In the tourism context, satisfaction, considered as the antecedent of loyalty [32], assumes strategic importance for destination marketing both to improve the quality of the service/product and to identify the type of service/product preferred by customers [33]. In this study the general satisfaction is a synthetic latent variable emerging from the six items reported in Table 1, that were measured using a Likert scale $1-5$ for each one.

Previous researches have highlighted several benefits resulting from a travel experience [34]-[37]. For young travellers these benefits include advancing education, cultural exchange, socialization, openness to new experiences, developing fundamental principles, (re)creating one's own personality, growing life skills, and experiencing individual transformation [35], [38]-[40]. The benefits perceived by tourists after a travel experience have been theoretically summarized in two main groups of change through travel, i.e. interpersonal change (e.g. cultural exchange and socialization) and personal change (e.g. increased knowledge through education, and experiencing individual transformation) [9], [38]. In the literature change in the relationship with the natural environment is seldom addressed [10]. On the basis of the existing literature and previous research by the same authors, the present study proposes several items to measure perceived change including change towards nature [10]. Whether people may change is a much-debated issue spanning several disciplines. It goes beyond the scope of this study to reconstruct this debate. Reference is therefore made to the Self Determination Theory (SDT) proposed by Ryan and Deci [42] that, differently from other psychological perspectives, postulates that people are intrinsically motivated to grow [43]. SDT supports the dichotomy between personal and interpersonal change highlighted above, and frames interpersonal change as a selftranscending desire to advance another people's life. The question has been raised whether tourism may be conductive of change, and particularly self-transcending change, due to its short-lived [4] and hedonic nature. In other words, it has been argued that only experiences of particular length [4] or purposefully designed to tickle specific values (such as ecotourism, [43]) may be conductive of change. Concluding, while the transformative power of travelling is called out as essential to achieve a more environmentally conscious and sustainable form of tourism, there are serious doubts that tourism in general may deliver on its promise due to its transient and hedonic character. Moreover, when change is considered as a benefit of travelling, it is mostly framed in terms of interpersonal and intrapersonal change, and not in terms of transcendental change.

In this research, three change dimensions emerged as synthetic latent variables from the items reported in Table 1, that were measured using a Likert scale 1-5 for each one.

Finally, even though it represents a major force in society both from a material and an immaterial perspective, youth tourism is seldom investigated in an integrated way where several components of the travel experience, such as motivation satisfaction and change, are studied in their inter-relationship.

This study aims at addressing these gaps in the literature by assessing the role of motivation and satisfaction on perceived change, and by approaching change through travel as a multidimensional construct where alongside ' $\mathrm{Me}$ and You' and ' $\mathrm{Me}$ ' change also transcendental change towards 'All' may be identified. 


\section{RESEARCH METHOD}

Data gathering has taken place in August 2015 at Stenden University of Applied Sciences (now NHL Stenden) in the Netherlands, by means of a Computer Assisted Web Interview (c.a.w.i) survey, which reached students between 16 and 30 years of age. The questionnaire was tested in a pilot survey. In terms of age range the sample matches the definition of young travellers [15], [41]. The self-selected sample counts 395 respondents, exceeding the threshold of 300 units, which Comfrey and Lee [44] contemplate as good sample.

Travel needs (conceptualized as motivations) have been related to the evaluation of the travel experience (satisfaction and perceived change) using a structural equations model which, by combining the logic of factorial analysis and multiple regression, explains the link between the observed variables through the simultaneous solution of equations [45]. For this type of analysis, the 'Lavaan package' (SEM procedure) implemented in the R environment was used [46]. In Table 1, the observed items and the latent variables considered in the model are presented.

\section{RESULTS AND DISCUSSION}

This section is divided into two principal parts. The first one describes the sample; the second reports on the models results.

\subsection{Sample}

395 students completed the survey. The youngest students aged 16-20 represent the most consistent age group $(77.4 \%)$, followed by those aged $21-25(21.1 \%)$ and $26-30(1.5 \%)$. The sample's age distribution corresponds to that of students registered at the Dutch University where the study took place. Students enter university after high school round 18 years of age and leave generally after four years of education. Only 314 students have travelled independently ( $79.5 \%$ of the sample), that is without being accompanied by a parent or guardian [15]. Additionally, out of these 314 respondents only 256 completed the sections on motivation, satisfaction and perceived change relevant for this study, and were consequently suitable for the structural equation model. The gender and nationality distribution of the 256 respondents is reported in Table 2. The gender distribution is not totally balanced with $64.1 \%$ being female. This imbalance could be related to the selfselection of the sample. Most traveller students reached by the survey are Dutch (69.1\%), an expected outcome because data have been gathered at a Dutch University of Applied Sciences. The University's international atmosphere is reflected in the variety of nationalities of the other respondents $(30.9 \%)$.

\subsection{Structural equations model: motivation, satisfaction and perceived change}

Results show that motivations and satisfaction with the tourist experience exert an influence on the change perceived. As previously noted, to investigate the relationship between

Table 2: Overview of demographic data (gender and nationality).

\begin{tabular}{|l|l|c|}
\hline Variables & Categories & Percentage values \\
\hline \multirow{2}{*}{ Gender } & Men & 35.9 \\
\cline { 2 - 3 } & Women & 64.1 \\
\hline \multirow{2}{*}{ Nationality } & Dutch & 69.1 \\
\cline { 2 - 3 } & Other & 30.9 \\
\hline
\end{tabular}




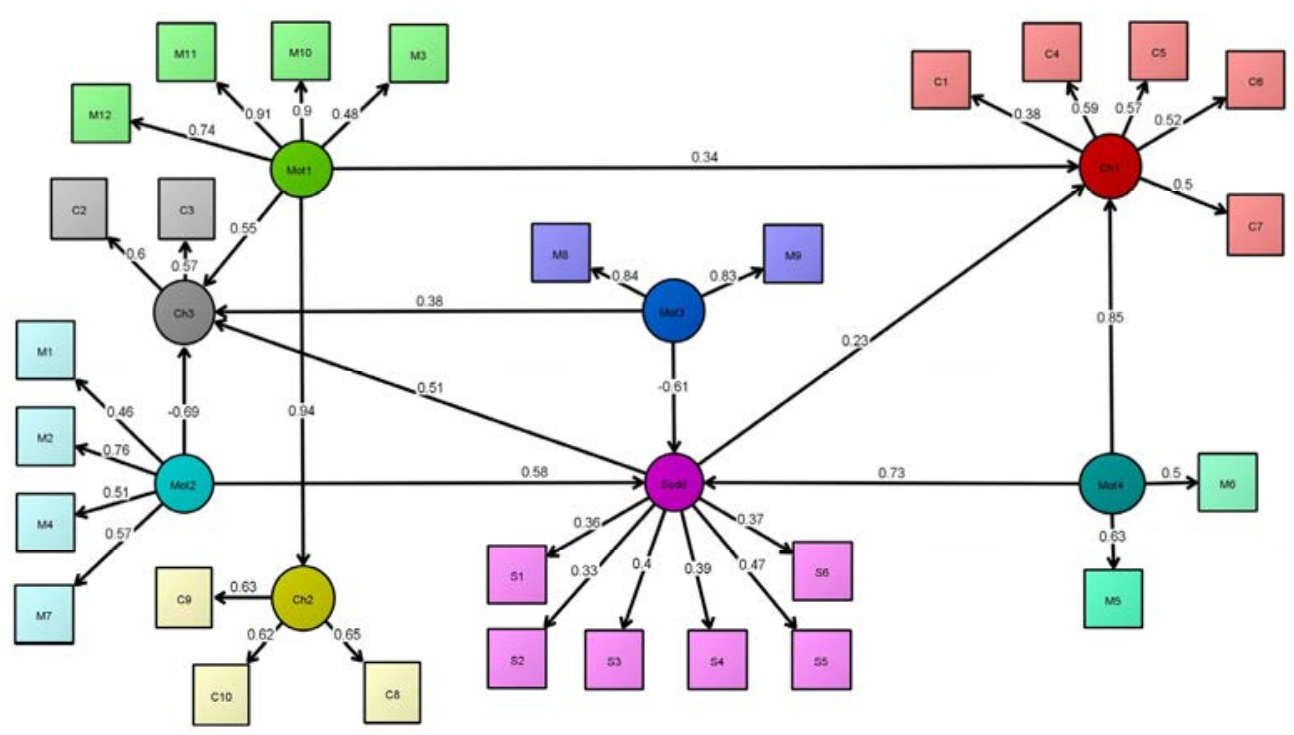

Figure 1: Structural equations model: motivation - satisfaction - change.

motivations, satisfaction and perceived change, a structural equation model has been used. Considering the observed items, in the hypothesized model several latent variables were constructed: four for motivation; three for change and one for satisfaction (Table 1). To assess the model's goodness, the indices obtained with the criteria of diagonal weighted least square estimation (DWLS) have been considered, as these are appropriate for ordinal data [47].

The model finds convergence after 66 iterations. The Comparative Fit Index (CFI), which compares the model with a null model (in which there are no factors) presents a value of 0.983 confirming the goodness of the model. The CFI, in the range of $0.97-1.00$, shows a good adaptation of the model [48]. The Fit index corrected with the number of parameters (Root Mean Square Error of Approximation (RMSEA)) also confirms the goodness of the model, being equal to 0.031 [48]. The estimates of the model are all statistically significant.

This study confirm that change is a multidimensional construct and identifies three types of perceive change. 'Me' or interpersonal change confirms that travel is an arena for selfdevelopment [38], while 'Me \& You' or intrapersonal change and 'All' or transpersonal change express relatedness [4], yet differently. While 'Me \& You' change relates to people, 'All' change enlarges the horizon of the traveller to his or her relationship with nature. In other words, while this result confirms the influence of a travel experience on personal growth and confirms that travelling may become a self-transcendent experience [4] [42] it also adds to the existing literature by distinguishing between two different self-transcending experiences: one directed towards other human beings and one directed towards nature. That self-transcendence may be thus divided has been demonstrated in socio-psychological studies on value orientations [49], [50] but as far as the authors know has not yet got profound attention in the study of (youth) tourism [10].

Moreover, and contrary to existing literature [4], results show that, notwithstanding tourism's mainly hedonic and short-lived character, any traveller has the chance to perceive change. However, this chance varies with the expressed motive for travelling - a result that will be discussed next. 
Results show that motivation influences perceived change. This first result is directly one of the most important from this study, because it confirms that to truly understand change as a benefit from travel researchers should not only consider the type of experience a young traveller undergoes (e.g. a gap year or an eco-tourism experience) [9], [11] but also the motives that underlie his or her choice for that experience.

Looking more specifically into the relationship between the four motivations and the three types of changes individuated in this study, it appears that only one motivation's type (motivation 1, labelled as Eco-sustainable motivation) influences positively all three types of change. Moreover, this is the only motivation that induces 'All' or transpersonal change, i.e. change in the relationship between the traveller and the natural environment. The influence of eco-sustainability motives on 'All' change is one of the strongest observed in the model (estimate 0.941). Travellers driven by an eco-sustainable motivation are prepared to and wish for an encounter with nature, and, as other studies have shown [13], [20] consider biospheric values more salient than other travellers. In other words, they feel the connection with the natural environment more strongly than others and are therefore more prone to perceive any change in this connection [20], [49], [50]. Considering the dyadic nature of the connection between the ' $I$ ' and 'nature', it is understandable that a change in the relation with nature implies also a change in the relation with the 'I', a type 1 or ' $\mathrm{Me}$ ' change. That travellers motivated by eco-sustainability also feel changed in their relationship with others may be explained with reference to the interconnectedness among biospheric and altruistic values [51].

The second motivation, labelled 'Fun and escaping' shows only one, negative, influence on 'Me and You' change. To interpret this result, it should be considered that except one ('to interact with my friends') all items composing the motivation 'fun and escaping' bear on the individual traveller sense of ease. The space for others' feelings is thus reduced, and the opportunity to feel changed in the relationship with others decreased. This confirms the notion that the hedonic character of travelling may impede to experience self-transcending change [52]. The absence of any influence on 'All change' may be explained on a similar line with reference to the difference between eudemonic and hedonic well-being [53]. While hedonic well-being increases when people seek fun and pleasurable activities, eudemonic well-being increases when people look for meaningful (such as self-development) or selftranscending (such as benefitting the local community) experiences [4]. Consequently, eudemonic and not hedonic wellbeing has been connected with the development of a more nature-caring and sustainable society [4], [54]. It is as if a focus on enjoyment undermines the traveller's sensitivity not only to others but also to nature, and thus the opportunity to change.

A different picture is shown by travellers driven by 'Vogue'. These youngsters are highly sensible to the opinions of other, let others' view guide their own choices and are, as results show, more highly sensitized than their peers to perceived changed in their relationship with others.

The fourth and last motivation extracted, 'Independence' influences the possibility to feel changed in the relation with oneself. Experiencing independence is part of the personal growth of the young traveller, and, so results show, contributes to opening the travellers' horizons. Interestingly, this motivation has the highest incidence on satisfaction, a variable that in its turn influence the perception of change in the relationship with nature. This result confirms the importance of 'independence' as a marker of personal and social growth [55] and confirms that independence should not be confused with the sense of easiness found in the second motivation. 
A second important result of this study is to have shown that motivations not only influence change but also influence satisfaction. Satisfaction is an important concept in the management and marketing of services because it has been shown to strongly influence loyalty. Loyalty in its turn has been positively linked to an organisation success [56]. Form here the interest to know how to influence customers' satisfaction. When looking at antecedents of satisfaction, literature mostly points to expectations, to the travel experience itself and to demographic variables. This study's results show that the reasons why people travel, have a direct impact on satisfaction and that therefore motivations should be considered when studying why travellers are or are not satisfied. In other words, individual motives should be recognized as influential on how a traveller evaluates his or her journey.

More precisely, all types of motivation individuated in this study influence satisfaction except the first, eco-sustainability. Motivation 3, Vogue, influence satisfaction negatively (estimate -0.609). Travellers motivated by Vogue concur with and follow another traveller's choice. This extrinsic motivation influences satisfaction negatively. Interestingly, the motivation 'Independence' has the highest positive impact on satisfaction. These travellers are animated by motives that may be framed as contrary compared to the ones cherished by their peers motivated by Vogue: they wish to feel more independent and meet people outside their circle of friends. This study's results therefore not only support previous research on the importance of independent travel for growth [55] but also position 'Independence' as a precondition of satisfaction. People motivated by 'Fun and Escapism' report also to be satisfied with their travel. Though this study has not looked at the type of experience, it may be argued that these travellers chose a destination in line with their desire to break from everyday life, and that this congruence of motivation and experience may explain their satisfaction. Future studies need to pursue this point further. It remains to be explained why the eco-sustainability motivation does not affect satisfaction. A tentative explanation is the different character of this motivation compared to the other three. While on one side it may be argued that all motivations are projected towards the travel experience and are connected to specific expectations (to experience nature; to be where everybody says you should be; to have fun; to become more independent), on the other the eco-sustainability motivation is unique because it does not relate to other people. Its connection with biospheric values, found in precedent research [13], leads to suspect that eco-sustainability motivated travellers have a subtler capacity of reflection and a more stable basis from which they relate to the natural world around themselves. Therefore, they may be less affected - either positively or negatively - by a single travel experience, and this equanimity may be reflected in the absence of an influence of the eco-sustainability motivation on satisfaction. This tentative explanation should be probed further in dedicated studies. Finally, let us consider the result concerning satisfaction. This variable is mostly studied as an antecedent of loyalty. The contribution of this article is showing that satisfaction is also an antecedent of perceived change. It does not affect change in the relationship with nature, a logical result considering that the ecosustainability motivation does not influence satisfaction. Yet it does influence personal ('Me') and interpersonal ('Me and You') change, both positively.

\section{CONCLUSION}

A first theoretically important result of this study is that it confirms the impact of a travel experience on personal growth [42]. More specifically, and in line with theories on value orientations developed in the field of pro-environmental psychology [49], [50], it confirms that travellers perceive changed not only in relationship with the self or others, but also in relation with nature. 
Moreover, since this study considers tourism experiences in general and not a specific form of tourism such as eco-tourism or spiritual retreats, it may safely be concluded that, notwithstanding tourism's mainly hedonic and ephemeral character, any traveller has the chance to perceive change. However, as the study has also shown, this chance varies with the expressed motive for travelling. In their recent study on tourism and well-being Smith and Diekmann [4] states that "debates are still ongoing about how best to define the ways in which tourism contributes to the positive experience of both tourists and local residents alike" and that there is a need to reach "[4] a deeper understanding of tourism as a phenomenon, especially insofar as it relates to motivation for, and participation in more meaningful, transformational or eudaimonic tourist experiences" [4, p. 2].

This study contributes by assessing the impact of travel motivation on perceived change, not only regarding relationship among human beings (the traveller; fellow travellers; the visited community), but also towards nature. Results imply that the concept of eudemonic tourist experiences can be expanded to comprehend nature and thus form a foundation for eco-friendly and more sustainable tourism experiences, intended as experiences [57]. Moreover, results clarify the influence of satisfaction on perceived change. Further studies are needed to probe this study's results in general, and particularly considering the impact of personal values on one side and the type of tourism experience on the other on the analysed constructs and their relationships.

\section{REFERENCES}

[1] Cavagnaro, E., Staffieri, S. \& Vrenegoor, F., The transformative power of travelling: A case study among youngsters studying in the Netherlands. EuroCHRIE: Nairobi Kenya, Conference EuroCHRIE, 23-26 Oct. 2017.

[2] UNWTO, United Nations World Tourism Organisation and World Youth Student \& Educational Travel Confederation Affiliate Members Global Reports, Volume 13, The Power of Youth Travel, UNWTO: Madrid, 2016.

[3] Dolnicar, S., Yanamandram, V. \& Cliff, K., The contribution of vacations to quality of life. Annals of Tourism Research, 39(1), pp. 59-83, 2012.

[4] Smith, M. \& Diekmann, A., Tourism and wellbeing. Annals of Tourism Research, 66, pp. 1-13, 2017.

[5] Chen, C.C. \& Petrick J.F., Health and wellness benefits of travel experiences: A literature review. Journal of Travel Research, 52(6), pp. 709-719, 2013.

[6] Gössling, S., Tourism, tourist learning and sustainability: An exploratory discussion of complexities, problems and opportunities. Journal of Sustainable Tourism, 26(2), pp. 292-306, 2018.

[7] Tribe, J. \& Liburd, J.J., The tourism knowledge system. Annals of Tourism Research, 57, pp. 44-61, 2016.

[8] UNWTO, Affiliate Members Global Report, Volume 14 - The Transformative Power of Tourism a Paradigm Shift towards a More Responsible Traveller, UNWTO: Madrid, 2016.

[9] Stafferi, S., L'esperienza turistica dei giovani italiani, Collana: Studi e Ricerche, Sapienza Università Editrice: Roma, 2016.

[10] Cavagnaro, E. \& Staffieri, S., Change as a benefit from travelling: for 'me', for 'me \& you' or for 'all'? A case study among students studying in the Netherlands. Tourism 2016, Proceedings of the International Conference on Global Tourism and Sustainability, Lagos, Portugal, 14-16 Oct. 2016, eds S. Lira, A. Mano, C. Pinheiro \& R. Amoêda, Barcelos: Green Lines Institute for Sustainable Development, pp. 115124, 2016. 
[11] Staffieri, S., Cavagnaro, E. \& Rowson, B., Change as a travel benefit: Exploring the impact of travel experiences on Italian youth. Research in Hospitality Management, 7(2), pp. 1-9, 2017.

[12] Veiga, C., Santos, M.C., Águas, P. \& Santos, J.A.C., Are millennials transforming global tourism? Challenges for destinations and companies". Worldwide Hospitality and Tourism Themes, 9(6), pp. 603-616, 2017.

[13] Cavagnaro, E. \& Staffieri, S., A study of students' travellers values and needs in order to establish futures patterns and insights. Journal of Tourism Futures, 1(2), pp. 94 $107,2015$.

[14] Fermani, A., Crocetti, E. \& Carradori, D., I Giovani e la Vacanza: Tratti di Personalità e Motivazione alla Scelta, Edizioni Università di Macerata: Macerata, 2011.

[15] United Nations World Tourism Organization \& World Youth Student \& Educational Travel Confederation, Youth Travel Matters: Understanding the Global Phenomenon of Youth Travel, UNWTO: Madrid, 2008.

[16] Richards, G. \& Wilson, J., The international student travel market, travel style, motivations, and activities. Tourism Review International, 8(2), pp. 57-67, 2004.

[17] Leask, A., Fyall, A. \& Barron, P., Generation Y: Opportunity or challenge - strategies to engage Generation Y in the UK attractions sector. Current Issues in Tourism, 16(1), pp. 17-46, 2013.

[18] Ruspini, E., Gilli, M. \& Decataldo, A., Turismo Generi Generazioni, Zanichelli: Bologna, 2013.

[19] Barton, C., Haywood, J., Jhunjhunwala, P. \& Bhatia, V., Travelling with Millennials, The Boston Consulting Group, S.P., 2013. www.bcg.com/documents/file129974.pdf. Accessed on: 12 Dec. 2017.

[20] Cavagnaro, E., Staffieri, S. \& Postma, A., Understanding millennials' tourism experience: values and meaning to travel as a key for identifying target clusters for youth (sustainable) tourism. Journal of Tourism Futures, in press.

[21] Moisă, C., Aspects of the youth travel demand. Annales Universitatis Apulensis Series Oeconomica, 12(2), pp. 575-582, 2010.

[22] Chang, J.C., Travel motivations of package tour travellers. Original Scientific Paper, 55(2), pp. 157-176, 2007.

[23] March, R.G. \& Woodside, A.G., Tourism Behavior: Travelers'Decisions and Actions, CABI Publishing: Cambridge, 2005.

[24] Cromton, J.L., Motives for pleasure vacation. Annals of Tourism Research, 1(4), pp. 408-424, 1979.

[25] Pearce, P.L. \& Lee, U.L., Developing the travel career approach to tourist motivation. Journal of Travel Research, 43(3), pp. 226-237, 2005.

[26] Huang, S., Measuring tourist motivation: Do scales matter? Tourismos: An International Multidisciplinary Journal of Tourism, 5(1), pp. 153-162, 2010.

[27] Nickerson N.P., Kerstetter, D., Bricker, K. \& Andereck, K., Understanding visitors' experiences: Methodological comparisons. In Measuring the Tourism Experience: When experience rules, what is the metric of success? Conference Proceedings of the Travel and Tourism Research Association, Montreal, Quebec, 20-23 Jun. 2004.

[28] Pearce, P. \& Packer, J., Minds on the move: New links from psychology to tourism. Annals of Tourism Research, 40(1), pp. 386-411, 2013.

[29] Gao, Y.L. \& Mattila, A.S., Improving consumer satisfaction in green hotels: The roles of perceived warmth, perceived competence, and CSR motive. International Journal of Hospitality Management, 42, pp. 20-31, 2017. 
[30] San Martín, H. \& Rodríguez del Bosque, I., Exploring the cognitive-affective nature of destination image and the role of psychological factors in its formation. Tourism Management, 29(2), pp. 263-277, 2008.

[31] Ladhari, R., The effect of consumption emotions on satisfaction and word-of-mouth communications. Psychology \& Marketing, 24(12), pp. 1085-1108, 2007.

[32] Gursoy, D., Chen, J.S. \& Chi, C.G., Theoretical examination of destination loyalty formation. International Journal of Contemporary Hospitality Management, 26(5), pp. 809-827, 2014.

[33] Kozak, M. \& Rimmington, M., Tourist satisfaction with Mallorca, Spain, as an offseason holiday destination. Journal of Travel Research, 38(3), 260-269, 2000.

[34] Chen, C.C., Petrick, J.F. \& Shahvali, M., Tourism experiences as a stress reliever: Examining the effects of tourism recovery experiences on life satisfaction. Journal of Travel Research, 55(2), pp. 150-160, 2016.

[35] Stone, M.J. \& Petrick, J.F., The educational benefits of travel experiences: A literature review. Journal of Travel Research, 52(6), pp. 731-744, 2013.

[36] Chen, C.C. \& Petrick, J. Health and wellness benefits of travel experiences: A literature review. Journal of Travel Research, 52(6), pp. 709-719, 2013.

[37] Durko, A.M. \& Petrick, J.F., Family and relationship benefits of travel experiences: A literature review. Journal of Travel Research, 52(6), pp. 720-730, 2013.

[38] Leed, E.J., The Mind of the Traveler. From Gilgamesh to Global Tourism. Basic Books: New York, 1991.

[39] Higgins-Desbiolles, F., More than an "industry": The forgotten power of tourism as a social force. Tourism Management, 27, pp. 1192-1208, 2006.

[40] Smed, K.M., Tourism \& Identity: Accumulated Tourist Experience and Travel Career Narratives in Tourists' Identity Construction (SPIRIT PhD Series, No. 23), Institut for Historie, Internationale Studier og Samfundsforhold, Aalborg Universitet: Aalborg, 2009.

[41] Moisă, C. \& Minciu, R., Fundamental aspects regarding youth and their decision to practice tourism. Annales Universitatis Apulensis Series Oeconomica, 11(2), pp. 1009-1018, 2009.

[42] Ryan, R.M. \& Deci, E.L., Intrinsic and extrinsic motivations: Classic definitions and new directions. Contemporary Educational Psychology, 25, pp. 54-67, 2000.

[43] Reisinger, Y. (ed.), Transformational Tourism: Host Perspectives, CABI Publishing: Wallingford, 2015.

[44] Comfrey, A.L. \& Lee, H.B., A First Course in Factor Analysis, Lawrence Erlbaum Associates: Hillsdale, NJ, 1992.

[45] Bollen, K.A., Structural Equation with Latent Variables, Wiley: New York, 1989.

[46] Rosseel, Y., Lavaan: An R package for structural equation modeling. Journal of Statistical Software, 48(2), pp. 1-36, 2012.

[47] Mîndrilă, D., Maximum Likelihood (ML) and diagonally weighted least squares (DWLS) estimation procedures: A comparison of estimation bias with ordinal and multivariate non-normal data. International Journal of Digital Society, 1(1), pp. 6066, 2010.

[48] Baggio, R. \& Klobas, J., Quantitative Methods in Tourism: A Handbook, Channel View Publications: Bristol, 2011.

[49] Steg, L., Bolderdijk, J.W., Keizer, K. \& Perlaviciute, G., An integrated framework for encouraging pro-environmental behaviour: The role of values, situational factors and goals. Journal of Environmental Psychology, 38, pp. 104-115, 2014. 
[50] Steg, L., Perlaviciute, G., Van der Werff, E. \& Lurvink, J., The significance of hedonic values for environmentally relevant attitudes, preferences, and actions. Environment and Behavior, 46(2), pp. 163-192, 2012.

[51] de Groot J.I.M. \& Steg L., Relationships between value orientations, self-determined motivational types and pro-environmental behavioural intentions. Journal of Environmental Psychology, 30(4), pp. 368-378, 2010.

[52] Kim, J.-H., Ritchie, J.R.B. \& McCormick, B., Development of a scale to measure memorable tourism experiences. Journal of Travel Research, 51(1), pp. 12-25, 2012.

[53] McMahan, E.A. \& Estes, D., Measuring lay conceptions of well-being: The beliefs about well-being scale. Journal of Happiness Studies, 12, pp. 267-287, 2011.

[54] Easterlin, R.A., Happiness, growth and public policy. Economic Inquiry, 51(1), pp. 1$15,2013$.

[55] Bianchi, C., Solo holiday travellers: Motivators and drivers of satisfaction and dissatisfaction. International Journal of Tourism Research, 18, pp. 197-208, 2015.

[56] Cruz Ruiz, E., Bermúdez González, G. \& Tous Zamora, D., Destination image, satisfaction and destination loyalty in cruise tourism: the case of Malaga (Spain). Tourism \& Management Studies, 14(1), pp. 58-68, 2018.

[57] United Nations World Tourism Organisation (UNWTO), Tourism Highlights, 2013 edition, UNWTO: Madrid, 2013. 